\title{
Vaccination of rainbow trout Oncorhynchus mykiss against the visceral form of coldwater disease
}

\author{
A. Obach, F. Baudin Laurencin \\ Laboratoire de Pathologie des Animaux Aquatiques, Centre National d'Etudes Vétérinaires et Alimentaires, BP 70, \\ F-29280 Plouzane, France
}

\begin{abstract}
The vaccinal efficacy of a heat-inactivated strain of Flexibacter psychrophilus, the bacterium responsible in France for the visceral form of coldwater disease, was tested after intraperitoneal (IP) or bath vaccination. The level of protection was determined by the survival of fish after IP injection challenge with the live bacterium. After IP vaccination of $2.2 \mathrm{~g}$ fish, a relative percent survival value of 80 was obtained. Bath vaccination provided a lower but still significant protection in fish vaccinated at $50 \mathrm{~d}$ post-hatch or later. No protection was observed in fish vaccinated at 30 or $40 \mathrm{~d}$ post-hatch.
\end{abstract}

\section{INTRODUCTION}

A visceral form of bacterial coldwater disease has occurred in France in recent years in rainbow trout Oncorhynchus mykiss (R.), causing very important losses in fry and fingerlings (Baudin Laurencin et al. 1988). The aetiological agent was Flexibacter psychrophilus (Bernardet \& Grimont 1989). Previously, this pathogen was reported from juvenile salmonids in North America in which it induced primarily cutaneomuscular and gill lesions (Bullock et al. 1971). In contrast, in France, lesions have consistently been detected in the internal organs, the gills being affected only infrequently. Such lesions were experimentally reproduced by intraperitoneal injection of the live bacterium (Baudin Laurencin et al. 1989). Holt (1987) obtained protection by vaccination against the American form of the disease. The present work describes experiments (1) to test the efficacy of vaccination by the intraperitoneal (IP) and immersion routes against the visceral form of coldwater disease (VCWD), and (2) to determine the age of the fish at which bath vaccination induces an immune protection.

\section{MATERIALS AND METHODS}

Specimens. Ca 5000 healthy rainbow trout fry, derived from eggs from 2 different pairs of parents and held in the laboratory, were used in 2 simultaneous experiments (January to May 1989). After hatching, the fry were distributed in $12 \mathrm{l}$ tanks that were supplied with filtered and well-oxygenated water. On first feeding ( $30 \mathrm{~d}$ post-hatch), fish were fed a commercial trout diet, ad libitum, during the first $4 \mathrm{wk}$; thereafter, the fish were fed at $4 \%$ of body weight.

Bacterin preparation. Bacteria isolated from a French outbreak of VCWD were cultured at $20^{\circ} \mathrm{C}$ for $72 \mathrm{~h}$ on Anacker and Ordal agar (AOA) (Anacker \& Ordal 1955) supplemented with $10 \%$ foetal calf serum. Cells were harvested and sterile physiological saline $(0.85 \% \mathrm{NaCl})$ was added to obtain an optical density of 0.6 at $625 \mathrm{~nm}$. Cell concentration, determined by epifluorescence microscopy, was ca $10^{10}$ cells $\mathrm{ml}^{-1}$. The suspension was inactivated by heating at $100{ }^{\circ} \mathrm{C}$ for 60 min and then diluted with sterile physiological saline to obtain a final concentration of $4 \times 10^{9}$ cells $\mathrm{ml}^{-1}$ for the first experiment and $7 \times 10^{8}$ cells $\mathrm{ml}^{-1}$ for the second.

Vaccination. To test the efficacy of the bacterin, an IP vaccination was carried out on $2.2 \mathrm{~g}$ rainbow trout fry (90 d post-hatch; temperature $11^{\circ} \mathrm{C}$ ). Three replicates of 25 fry were intraperitoneally injected with $0.1 \mathrm{ml}$ of a dilution of the bacterin containing $3.5 \times 10^{9}$ cells $\mathrm{ml}^{-1}$. In addition, bath vaccinations were performed in 2 experiments on fish at $30,40,50,60,70,80$, 90 or $100 \mathrm{~d}$ post-hatch (see Table 1 ). At each vaccination time, 4 replicates of 50 fish were immersed in the diluted bacterin suspension for $2 \mathrm{~min}$. Four other repli- 
cates were handled in the same way but were immersed in sterile physiological saline.

Challenges. Challenges were performed 35 to $40 \mathrm{~d}$ after vaccination. Fish were anaesthetized with ethylene-glycol-monophenyl-ether and then challenged by intraperitoneal injection with $0.05 \mathrm{ml}$ of Flexibacter psychrophilus suspension. Challenge doses were first standardized turbidometrically (optical density at 625 $\mathrm{nm}$ ). Plate counts were then made to determine the dose of viable cells administered. Dead fish were collected daily and necropsied. The presence of F psychrophilus in the dead fish was established microscopically using spleen tissue samples and by isolation on AOA using randomly chosen samples. Experiments were terminated ca $20 \mathrm{~d}$ post challenge if there had been no losses for 3 or $4 \mathrm{~d}$.

Statistical analysis. Statistical analysis was carried out using a computerized STATITCF statistical system (Institut Technique des Céréales et des Fourrages, Boigneville, France). The effect of vaccination (deaths in controls vs in vaccinated) on the mortality rate after challenge was checked by a 1-way analysis of variance (ANOVA; $p=0.05$ ). The relative percent survival (RPS) (Amend 1981) was calculated when significant differences between the mortalities in the control and vaccinated groups occurred.

\section{RESULTS}

Following challenge, mortalities began at 4 to $7 \mathrm{~d}$ and lasted for 13 to $17 \mathrm{~d}$. All dead fish were positive for
Flexibacter psychrophilus. Apart from melamosis and exophthalmia (both evident externally), lesions were observed only on the visceral organs and were similar to those observed in the field outbreaks of VCWD.

In IP-vaccinated fish, the post-challenge mortality rate was significantly lower $(11 \%)$ than in control groups (55\%). An RPS value of $80 \%$ was obtained.

The RPS values of bath-vaccinated fish are shown in Table 1. In fish vaccinated at $50 \mathrm{~d}$ post-hatch or later, the RPS values ranged from 14 to $47 \%$. No protection was demonstrated in fish vaccinated at 30 or 40 d posthatch.

\section{DISCUSSION}

Although IP vaccination of fish (especially fry) is an impractical method, it is known to provide the strongest immunity achievable in fish (Evelyn \& Ketcheson 1980); it therefore serves as a convenient method for assessing the potential usefulness of a bacterin. The RPS value obtained with our bacterin following IP vaccination $(80 \%)$ was not as high as that (almost $100 \%$ protection) obtained by Holt (1987) in his studies with 0.5 to $27.0 \mathrm{~g}$ coho salmon Oncorhynchus kisutch. However, Holt used a higher dose of injected bacterin, and bacterin was administered with an immuno-stimulatory preparation (Cossarini-Dunier 1983). Notwithstanding this, our bacterin was clearly shown by injection to be immunogenic and thus worthy of further study

Using our bacterin, we showed that it was possible to protect juvenile rainbow trout against the visceral

Table 1. Oncorhynchus mykiss infected with Flexibacter psychrophilus. Mortality rate ( \pm standard error) and relative percent survival (RPS) values in rainbow trout fry after intraperitoneal injection challenges. Vaccination dose was $4.0 \times 10^{9} \mathrm{cells}^{\mathrm{m}} \mathrm{l}^{-1}$ in

Expt 1 and $7 \times 10^{8}$ cells $\mathrm{ml}^{-1}$ in Expt 2 . Mean mortality rates are given for 4 replicates of 50 fish; vacc: vaccinated groups

\begin{tabular}{|c|c|c|c|c|c|c|c|}
\hline \multicolumn{3}{|c|}{$\begin{array}{l}\text { Fry characteristics and temp- } \\
\text { erature at vaccination time }\end{array}$} & \multirow{2}{*}{$\begin{array}{l}\text { Challenge dose } \\
\text { (cells } \text { fish }^{-1} \text { ) }\end{array}$} & \multirow{2}{*}{$\begin{array}{c}\text { Temp at } \\
\text { challenge } \\
\left({ }^{\circ} \mathrm{C}\right)\end{array}$} & \multirow{2}{*}{$\begin{array}{l}\text { Mean mortal. } \\
\text { rate, control } \\
(\%)\end{array}$} & \multirow{2}{*}{$\begin{array}{c}\text { Mean mortal. } \\
\text { rate, vacc. } \\
(\%)\end{array}$} & \multirow[t]{2}{*}{ RPS } \\
\hline $\begin{array}{c}\text { Age (d } \\
\text { post-hatch) }\end{array}$ & $\begin{array}{l}\text { Weight } \\
\text { (g) }\end{array}$ & $\begin{array}{c}\text { Temp. } \\
\left({ }^{\circ} \mathrm{C}\right)\end{array}$ & & & & & \\
\hline \multicolumn{8}{|l|}{ Expt 1} \\
\hline 30 & 0.20 & 9.0 & $1.0 \times 10^{7}$ & 11.0 & $98.3 \pm 1.0$ & $99.0 \pm 0.9$ & - \\
\hline 40 & 0.35 & 9.5 & $7.0 \times 10^{5}$ & 9.5 & $78.0 \pm 2.4$ & $82.7 \pm 4.0$ & - \\
\hline 50 & 0.50 & 8.5 & $6.2 \times 10^{5}$ & 9.0 & $61.0 \pm 4.1$ & $32.5 \pm 0.8$ & 47 \\
\hline 60 & 1.10 & 9.0 & $2.0 \times 1.0^{6}$ & 10.0 & $96.5 \pm 0.8$ & $79.5 \pm 2.9$ & 18 \\
\hline \multicolumn{8}{|l|}{ Expt 2} \\
\hline 30 & 0.20 & 10.0 & $2.0 \times 10^{5}$ & 9.5 & $73.0 \pm 2.7$ & $78.7 \pm 2.2$ & - \\
\hline 40 & 0.35 & 9.5 & $3.4 \times 10^{5}$ & 10.0 & $95.7 \pm 0.9$ & $89.2 \pm 2.6$ & - \\
\hline 50 & 0.50 & 7.0 & $8.2 \times 10^{5}$ & 11.0 & $79.7 \pm 1.7$ & $53.0 \pm 2.5$ & 34 \\
\hline 60 & 0.80 & 10.0 & $1.1 \times 10^{6}$ & 11.0 & $98.2=0.5$ & $84.7 \pm 1.4$ & 14 \\
\hline 70 & 1.20 & 10.0 & $1.3 \times 10^{6}$ & 11.5 & $92.5 \pm 1.4$ & $73.2 \pm 2.3$ & 21 \\
\hline 80 & 1.45 & 11.5 & $1.0 \times 10^{b}$ & 14.0 & $72.0 \pm 2.8$ & $42.7 \pm 1.3$ & 4.1 \\
\hline 90 & 2.20 & 11.0 & $1.7 \times 10^{6}$ & 14.5 & $77.5 \pm 1.6$ & $48.5 \pm 1.7$ & 37 \\
\hline 100 & 4.20 & 11.0 & $2.9 \times 10^{6}$ & 17.0 & $86.0 \pm 1.8$ & $62.5 \pm 2.2$ & 27 \\
\hline
\end{tabular}


form of coldwater disease and that this protection could be achieved by the practical means of bath vaccination. This protection, however, did not occur with fish $<50 \mathrm{~d}$ from hatching (and weighing $<0.5 \mathrm{~g}$ ); it occurred only in fish $\geq 50 \mathrm{~d}$ from hatching and weighing $\geq 0.5 \mathrm{~g})$. The resulting protection, expressed in terms of RPS values, varied considerably (14 to $47 \%$ ), perhaps a function of variations in factors such as water temperature and challenge dose, which proved unavoidable (Table 1). Notwithstanding these variations, the overall findings indicating that immunocompetence comenced at ca $50 \mathrm{~d}$ post-hatching (or at a weight of $0.5 \mathrm{~g}$ ) are considered to be valid, as they occurred in 2 separate experiments.

Failure of bath vaccination to provide protection in fry at Days 30 and 40 post-hatch (and weighing 0.20 and $0.35 \mathrm{~g}$ respectively) was not surprising. Tatner \& Manning (1982) showed that the number of lymphocytes in the haematopoietic organs of very young fish was small and that the number correlated more with fish weight than with fish age. This probably explains why, in several species of salmonids tested, immunity appeared to be more a function of fish size than fish age (Johnson et al. 1982). Johnson et al. (1982) found that the minimum weight at vaccination needed to ensure good protection was between 1.0 and $2.5 \mathrm{~g}$. In the experiments of Holt (1987), a satisfactory level of immunity following bath vaccination occurred only when the fish had reached the $1.0 \mathrm{~g}$ stage. Immunocompetence in rainbow trout at the $0.5 \mathrm{~g}$ stage, as we found in the present experiment, is consistent with findings of Tatner \& Horne (1983) for this species (the latter workers used a bath-administered anti-Vibrio anguillarum vaccine). Thus, while age or size at immunocompetence may vary somewhat with the species, stock, or history of the fish, the important point is that vaccination at too early a stage may be a wasted effort.

In the present study we chose to use an IP challenge even though this challenge method is considered to be a drastic one. The challenge method was used because it resulted in typical signs of natural VCWD and because earlier attempts at bath challenges did not produce sufficiently high mortality levels for evaluating the protectiveness of the vaccine. Challenge by the IP method bypasses the immunity that is believed to developed locally in the integulment as a result of bath vaccination (Ellis 1988). Thus the benefits of the immune response, as measured in our laboratory, may actually represent underestimates of the benefits in survival accruing to the fish under conditions of natural challenge in the field. The outlook is good, there- fore, that bath vaccination may prove a practical and economically worthwhile measure for controlling VCWD in fish culture facilities.

Acknowledgements. A. Obach was supported by a grant from the Spanish Ministry of Education and Science.

\section{LITERATURE CITED}

Amend, D. F. (1981). Potency testing of fish vaccines. Dev. Biol. Standard. 49: 447-454

Anacker, R. L., Ordal, E. J. (1955). Study of a bacteriophage infecting the myxobacterium Chondrococcus columnaris. J. Bacteriol. 70(6): 738-741

Baudin Laurencin, F., Castric, J., Vigneulle, M., Tixerant, G. (1988). La myxobactériose viscérale de la truite arc-enciel, essais thérapeutiques. Piscic. fr. 94: 3-6

Baudin Laurencin, F., Castric, J., Vigneulle, M., Tixerant, G. (1989). La myxobactériose viscérale de la truite arc-en-ciel Salmo gairdneri R.: une forme nouvelle de la maladie de l'eau froide à Cytophaga psychrophila. Bull. Acad. vet Fr. 62: 147-157

Bernardet, J. F., Grimond, P. A. (1989). Deoxyribonucleic acid relatedness and phenotypic characterization of Flexibacter columnaris sp. nov., nom. rev., Flexibacter psychrophilus sp. nov., nom. rev., and Flexibacter maritimus Wakabayashi, Hikida, and Masumura 1986. Int. J. syst. Bact. 39(3): $346-354$

Bullock, G. L., Conroy, D. A., Snieszko, S. F. (1971). Myxobacterioses, peduncle and coldwater disease. In: Snieszko, S F., Axelrod, H. R. (eds.) Diseases of fishes. T.F.H. Publication, Jersey City, New Jersey, p. 74-77

Cossarini-Dunier, M. (1983). Etude de la réponse humorale de la truite arc-en-ciel (Salmo gairdneri) à des antigène solubles: mémoire immunitaire, essais d'adjuvants, perspectives offertes par l'utilisation des truites à l'hétérogénéité génétique restreinte. Thèse de Doctorat 3ème cycle, Université de Paris VII

Ellis, A. E. (1988). General principles of fish vaccination. In: Ellis, A. E. (ed.) Fish vaccination. Academic Press, London, p. $1-19$

Evelyn, T P. T., Ketcheson, J. E. (1980). Laboratory and field observations on antivibriosis vaccines. In: Ahne, W. (ed.) Fish diseases. Third COPRAQ-Session. Springer-Verlag, Berlin, p. 45-52

Holt, R. A. (1987). Cytophaga psychrophila, the causative agent of bacterial cold-water disease in salmonid fish Ph.D. thesis. Oregon State University, Corvallis, Oregon

Johnson, K. A., Flynn, J. K., Amend, D. F. (1982). Onset of immunity in salmonid fry vaccinated by direct immersion in Vibrio anguillarum and Yersinia ruckeri bacterins. J. Fish Dis. 5: 197-205

Tatner, M. F., Horne, M. T. (1983). Susceptibility and immunity to Vibrio anguillarum in post-hatching rainbow trout fry, Salmo gairdneri Richardson 1936. Dev. comp. Immunol. 7: 465-472

Tatner, M. F., Manning, M. J. (1982). Growth of the lymphoid organs in rainbow trout, Salmo gairdneri, from one to fifteen months of age. J. Zool., Lond. 199: 503-520
Responsible Subject Editor: T. Evelyn, Nanaimo, B.C., Canada
Manuscript first received: March 19, 1990

Revised version accepted: September 24, 1991 